\title{
Predicting the Future Stock Return by Emphasizing on Life Cycle Based on Cash Flow Statement
}

\author{
Zahra Hashemi Oskouei", Rasoul Baradaran Hasan Zadeh \\ Department of Accounting, East Azarbaijan Science and Research Branch, Islamic Azad University of Tabriz, Tabriz, Iran
}

Copyright (C) 2015 by authors, all rights reserved. Authors agree that this article remains permanently open access under the terms of the Creative Commons Attribution License 4.0 International License

\begin{abstract}
The main purpose of this research is to investigate the future stock return considering the features of different stages of the life cycle based on the cash flow statement. In this research the stock return has been considered as dependent variable, Earning per share and the change in earnings as independent variables, and risk factors (the book value of equity to the market value of equity ratio, loss, firm size, market model beta) have been considered as control variables. Firstly, the statistical sample has been separated using cash flow pattern to the firms at the stage of the Introduction, Growth, Mature, Shake-Out and Decline, then in order to analyze the raw data and converting them to the information needed for making decision about hypotheses and explaining the relationships among the variables, the regression testing is used. The results obtained from the investigation of 1123 firms-years during the period between 2002 and 2011 indicate that generally the change in earnings per share has significant and positive effects on predicting the future stock return. But the effect of the earning per share on future stock return is insignificant and positive. In addition, the results of the test show that the lowest of the book value to market value ratio in mature stage has a positive effect on future stock return and the highest ratio in this stage has a negative effect on future stock return.
\end{abstract}

Keywords Predicting, Stock Return, Firm Life Cycle, Cash Flow Statement

\section{Introduction}

One of the most fundamental economic issues of the people, firms, and governments is optimized allocation of resources. Optimized allocation of resources is possible when the resources are directed toward productive investments with logical risk. Considering the necessity of investment in order to achieve economic development, offering solutions to optimize investment composition can be a positive step for encouraging investment and the investment market's being more active. In the procedure of decision making by the investors, directors, financial analysts, and other groups using the information, predicting the share return is one of the important factors for decision making [1].

The results of the studies available in literature indicate the important effect of life cycle on the accounting variables [2-5]. Considering the abovementioned issues, the main purpose of this research is to investigate the relationship among cash flows, future performance, and the life cycle of the firm. Other purposes of this study include investigating the role of results obtained from this study in capital market and their effect on estimating the expected return of the investors and evaluating them with the risks related to firms. As we know, the investors are interested to estimate the risk and return on investment, so it is expected that in case of realization of the results expected from the study, capital market investors and analysts must be able to separate the stages of life cycle of the firm in a more proper way, and apply them in the predictions and evaluations related to risk, return, dividend, better measuring of growth rate, achieving forecast horizons to evaluate models, and better understanding of the effectiveness of economic principles on profitability details, that will finally lead to adjusting and increasing the return expected by the shareholders and in macroeconomic prospective will lead to optimized allocation of resources and wealth.

\section{Literature Review}

\section{Life Cycle of the Firm}

Life cycle of the firm is one of the concepts that has been entered various fields related to firm during the recent decades [6]. Gardner [7] stated that the firm has its own unique life cycle; accordingly, this concept has been used in humanities studies such as microeconomics, management, accounting, and finance [6]. The main content of these studies is based on different stages in the life cycle of the firm and unique features of each stage $[8,9]$. Therefore, two main axes in the literature of firm life cycle are the models of 
firm life cycle stages and descriptor features of each stage. In accounting, the features such as age, growth in sales, capital expenses, size, growth and investment opportunity, capital cost , financial leverage, dividend, cash flow pattern, and capital structure for classifying the stages of firm life cycle are used [2,6,10-14]. There are also various firm life cycles that include Greiner's five-stage model [15], Gort and Klepper [16], Miller and Friesen [17], Adizes's [18] ten-stage model, and three-stage and two-stage models of Anthoni and Ramesh [2]. In this paper, the five stages which are common to economic literature of the firm life cycle will be mentioned.

Gort and Klepper [16] have defined five stages of the life cycle in an assumptive market, that include:

1. Introduction stage: a stage in which the first innovation is formed

2. Growth stage: a stage in which the number of producers is increasing

3. Mature stage: a stage in which the number of producers reaches its maximum

4. Shake-Out stage: a stage in which the number of producers is decreasing

5. Decline stage: a stage in which the net amount of entering the industry is almost zero.

These stages are the results of change in internal factors (such as selecting the strategy, financial resources, management ability) and external factors (such as competitive environment and macroeconomic factors), that most of them are created by strategic activities of the firms. Reviewing the economy theory that includes production behavior, learning, experience, investment, input and output models and the market share, indicates the unique features of the firm life cycle theory [12].

Introduction stage: in this stage, the most important special feature of the firms is that they are young, are directed by their owners, and have non-official organizational structure $[19,17]$. The firms enter the market with their incomplete information about the quality and quantity of their products, and get familiar with their potential and actual abilities by starting the operation through accounting and operational feedback. The more ambiguous these feedbacks are, the more risky the second investment for the firm is. So, the firms with higher unreliability level invest less because of risk management $[20,17]$

Growth stage: the firms make many investments in this stage due to optimistic expectations related to their abilities (including cost structure and competitive advantage). These investments (primary \& surpositive) do not just include tangible and financial assets, but contain organizational capital such as investment in distributional systems, productive infrastructure, and technological ability. Hence, the firms can earn temporary exclusive benefits [21]. The studies indicate that although the extent of demand for the products may be increasing, the products of the firms may not still been generally accepted by the consumers; of course they are more acceptable comparing with the emergence stage of the goods $[22,23]$.

Mature stage: the capacity of primary investment to meet the high market demand in the mature stage is sufficient and the firm will produce more input cash flow [24]. In this stage, the primary and second investments are obsolete; and their obsolescence depends on technological power of the industry [25]. Compared to the firms in other stages of life cycle, active firms have fewer changes in maturity stage. Stable environment leads to financial results that will not more deviation from the results of the previous year. Commercial risk of the maturity stage is relatively less than other stages of the life cycle [26].

Shake-Out stage: in case that the firms cannot restart their operation through structural changes (such as achievement, merging, and specific participation) or cannot enter new markets, entering the recession stage will be imminent. The firms try to convert their non-productive assets to cash or in other words, convert these resources to projects that create positive return [16].

Decline stage: in decline stage, if growth opportunities exist, they are limited. By the firms entrance to decline stage, commercial risk is also increased; as a result, the cost of financial supply of the firm is very high [3]. Generally, in this stage the firm faces reduction of sale extent and also technology substitution or even outdated products. In this stage the revenue of the firm is probably the minimum or negative and the investment return will be low usually because of the limited investment opportunities, general market drop, and operation loss [27].

\section{Stock Return}

The return of the common stock includes the revenue collection that accrues to share holder within a financial period as follows:

1. Price change: the changes of the share price within a period are one of the main factors of the return.

2. Cash dividend of each share: that is paid to the shareholders after tax deduction

3. Stock right: shareholders of the public firms have priority in buying the new shares that are issued by the firm after increasing the capital, and can use their right within the due time. This right has exchange value.

4. Stock dividend: some firms prefer to pay the dividend to the shareholders as stock dividend. So, instead of cash dividend, a number of shares are allocated to the shareholders.

Small firms usually show stronger reaction toward unreliability of the market and as a result there are more fluctuations in their prices. According to existing reports after controlling the systematic risk, the shares of small firms create more return in comparison with those of the big firms [28].

\section{Cash Flow Statement}

Operating activities: cash flows have negative sign in the 
introduction stage. In this stage the firms enter the market with incomplete information about potential revenues and costs [25]. Firms achieve the most profit margins in the growth stage $[21,29,30]$. The sign of cash flows is positive in this stage. In the mature stage, the efficiency reaches its maximum level due to the increasing the operational information [31], and the sign of cash flows is positive in the mature level. Cash flows in the shake-out stage can be both positive and negative [32]. In decline stage, decreasing the growth rates results in decreasing the prices [31], and cash flows resulting from operational activities is negative in this stage.

Investing activities: cash flows are negative in introduction stage and the firms move toward creating capacity and talent. In addition, by future investment in primary stages of the life cycle, the firms can create barriers for entrance $[21,29,30]$. Cash flow resulting from investing activities in growth stage is negative. In the mature stage, obsolescence increases relative to new investment until the net investment becomes negative [25]. Cash flows are both positive and negative in shake-out stage. In decline stage, the cash flows are positive.

Financing activities: In introduction stage, the firms supply their required funds through financial supply out of the firm [33,34]. Growth firms increase debt $[35,36,26]$ and the cash flows are positive in this stage. In the growth stage, the cash flows are still positive. In the mature level, the policy of financial supply of the firm is directed toward repayment of debts and distribution of funds among shareholders [33], and the cash flows are negative in this stage. In shake-out and decline stages, the cash flows are both positive and negative.

Collins et al. [5], considering their study mention that the firms that are in the primary stages of their life cycle have more temporal asymmetry of operational cash flow in comparison with the firms that are in later stages of their life cycle. Thanatawee [10], with her/his research in the firms accepted in Thailand Stock Exchange concluded that larger and more profitable firms with more free cash flows and logical earnings with regard to capital have more tendency for paying more dividend. Victoria Dickinson in her doctorate thesis [12] indicated that convergence of profitability and growth stimuli (profit margin \& asset turnover) are influenced by life cycle, and the stages of life cycle increase the prediction of these factors. Wang et al. [37] investigated the policy of dividend and life cycle. The results indicated that paying the dividend in young firms with high growth potential the distribution of dividend is more than cash dividend. Anthoni and Ramesh [2] have investigated the relationship between performance criteria with the price of share market in different stages of firm life cycle. The results of the study indicate that the reaction of share market toward two criteria of accounting performance, growth and sale and invested funds, after controlling the size, risk and measuring error in performance criteria, is a function of life cycle stages of the firm.

\section{Research Method}

This research is done in two stages: in the first stage the statistical samples are separated using the cash flow patterns to the firms in the stages of introduction, growth, mature, shake-out, and decline; then, using multivariate regression equations the research hypotheses are tested.

\section{Cash Flow Patterns}

One of the new methods to separate the stages of life cycle of the firm is cash flow patterns. Dickinson [12] separates the life cycle stages of the firm using models created by positive and negative signs of the cash flow statement (such as operating, investing, and financing activities). In this research, in order to separate the life cycle of the firms, this method is used (Table 1).

Table 1. Isolation of the stages in firm's life cycle.

\begin{tabular}{|c|c|c|c|c|c|c|c|c|}
\hline & 1 & 2 & 3 & 4 & 5 & 6 & 7 & 8 \\
\hline & Introduction & Growth & Maturity & $\begin{array}{c}\text { Shake-ou } \\
\mathrm{t}\end{array}$ & $\begin{array}{c}\text { Shake-ou } \\
\mathrm{t}\end{array}$ & $\begin{array}{c}\text { Shake-ou } \\
t\end{array}$ & Decline & Decline \\
\hline \multicolumn{9}{|l|}{ Predicted signs } \\
\hline $\begin{array}{l}\text { Cash flows from } \\
\text { operating activities }\end{array}$ & - & + & + & - & + & + & - & - \\
\hline $\begin{array}{c}\text { Cash flows from } \\
\text { investment activities }\end{array}$ & - & - & - & - & + & + & + & + \\
\hline $\begin{array}{l}\text { Cash flows from } \\
\text { financing activities }\end{array}$ & + & + & - & - & + & - & + & - \\
\hline
\end{tabular}


There are three net cash flow activities (operating, investing, and financing) and each type can take a positive or negative sign, resulting in $\left(2^{3}=8\right)$ possible combinations. Following cash flow patterns of Dickinson, in this method 8 patterns are considered for the life cycle of the firms. The eight patterns are collapsed into five stages. Considering that the cash flow statement prepared in five-class form in Iran, it is necessary to change it in 3-stage form in order to separate the stages of the life cycle.

\section{Research Hypotheses}

Hypothesis one: Earning per share is effective on future prediction of stock return.

Hypothesis two: The book value of equity to market value of equity ratio in future stock return prediction is effective considering the mature stage from life cycle stages resulting from the cash flow patterns.

In order to test the research hypotheses the following regression models are used:

1. $R E T_{i, t+1}=\alpha_{\circ}+\beta_{1} X / P_{i, t}+\beta_{2} \Delta X / P_{i, t}+$ $+\beta_{3}$ Loss $_{i, t}+\beta_{4}(X / P \times \text { Loss })_{i, t}+$ $\beta_{5} B / M_{i, t}+\beta_{6}$ Size $_{i, t}+\beta_{7}$ Beta $_{i, t}+\varepsilon_{i, t+1}$

Dependent variable that is used in the present study is the future stock return.

\section{Independent Variables of the Research}

4. $R E T_{i, t+1}=\alpha_{\circ}+\beta_{1} X / P_{i, t}+\beta_{2} \Delta X / P_{i . t}+\beta_{3} \operatorname{Loss}_{i, t}+$ $+\beta_{4}(X / P \times \text { Loss })_{i, t}+\beta_{5} B / M_{i, t}+\beta_{6}$ Size $_{i, t}+$ $\beta_{7}$ Beta $_{i, t}+\beta_{8}$ Mature $_{i, t}+\beta_{9}(\text { Mature } \times \text { LowB } / M)_{i, t}+$ $+\beta_{10}(\text { Mature } \times \text { HighB } / M)_{i, t}+\varepsilon_{i, t+1}$

Earning per share $(\mathrm{X} / \mathrm{P})$, scaled by stock price.

The change in earning per share $(\triangle \mathrm{X} / \mathrm{P})$, equals earning per share divided by the average of each share's price during the year.

\section{Control Variables of the Research}

The book value to market value equity ratio $(\mathrm{B} / \mathrm{M})$ : = Book value of equity

market value of equity

Loss: is set to one if the company incurs a loss, otherwise, code 0 is considered for it.

\section{Market Model Beta}

$$
\mathrm{B}=\frac{\operatorname{COV}\left(R_{i t}, R_{m t}\right)}{\vartheta^{2}\left(R_{m t}\right)}
$$

$\mathrm{Rm}$ is the market portfolio and Rit is the return of each $\mathrm{i}$ share at $\mathrm{t}$ time.
Size: log of market value of equity at the end of the period.

Moderating variables: equals the earning per share multiplied by the loss ( $\left.\mathrm{x} / \mathrm{p}^{*} \operatorname{loss}\right)$. is set to one if the company incurs a loss, otherwise, code 0 is considered for it.

Mature: the mature stage is based on cash flow pattern according to the classification. If the firm is in mature stage at the end of the financial period, we consider code 1 for it; otherwise code 0 is considered for it.

(Mature*low $\mathbf{B} / \mathbf{M})=$ is the lowest book value to the market value equity ratio at the end of financial period multiplied by the mature-value firms.

(Mature*high $\mathbf{B} / \mathbf{M})=$ is the highest book value to the market value equity ratio at the end of financial period multiplied by the mature-value firms.

Testing the hypothesis one: To test this hypothesis, the regression model 1 following the model of Collins et al. [38] and Fama et al. [39] is fit. In this model, the life cycle is not considered. The earning per share and change in earnings in this model have considerable explanatory power for the return of the annual stock. Previous researches have demonstrated a differential response to loose versus positive earnings differential response [40,41]. So an indicator variable loss is set to one if the company incurs a loss; otherwise, code 0 is considered for it. Loss variable has a considerable effect and a mutual effect on the earnings [12].

Testing the hypothesis two: To test this hypothesis, the regression model 2 is fit for the stages of life cycle. In this model, if the firm is in maturity stage we consider code 1 for it; otherwise code 0 is dedicated to it.

\section{Population and Statistical Sample}

The statistical population of this study includes the firms inserted in the list of Tehran Stock Exchange within 2002 to 2011, whose information has been investigated for a 10-year period.

Since in this study the population includes all firms accepted in Tehran Stock Exchange and also considering the abovementioned time limit mentioned of this study, the following criteria have been used in order to select the proper sample using elimination method:

1) The sample selected for the present research should not be chosen from among investment companies, financial intermediaries, holdings, banks, or leasing.

2) To establish comparability, fiscal year of the companies should end on 21 March.

3) Financial information of the companies for the period under investigations should be accessible.

4) Companies should not have changed their fiscal year during financial period.

5) Companies should not have been chosen from among those put aside from Stock Exchange.

Accordingly and after applying the above mentioned limitations, 114 firms had the mentioned conditions within the time period 2002 to 2011 and were considered as the statistical sample of the research. 


\section{Research Findings}

Table 2 shows the descriptive statistics, independent and dependent variables.

Table 2. Descriptive statistics

\begin{tabular}{cccccc}
\hline Variable & N. of observations & Mean & Standard deviation & Minimum & maximum \\
\hline B/M & 1123 & $\mathbf{0 / 6 2 9}$ & $\mathbf{0 / 6 3 9}$ & $\mathbf{- 2 / 1 7}$ & $\mathbf{8 / 5 2}$ \\
BETA & 1123 & $\mathbf{0 / 6 4 4}$ & $\mathbf{3 / 5 2 3}$ & $\mathbf{- 3 / 7 2}$ & $\mathbf{7 / 8 8}$ \\
SIZE & 1123 & $\mathbf{5 / 6 2 6}$ & $\mathbf{0 / 7 9 8}$ & $\mathbf{3 / 6 6}$ & $\mathbf{9 / 2 2}$ \\
RET & 1123 & $\mathbf{1 / 1 4 2}$ & $\mathbf{3 / 9 1 7}$ & $\mathbf{- 2 / 0 1}$ & $\mathbf{5 / 5 0}$ \\
X/P & 1123 & $\mathbf{0 / 0 6 1}$ & $\mathbf{0 / 4 4 2}$ & $\mathbf{- 5 / 7 5}$ & $\mathbf{7 / 3 5}$ \\
XX/P & 1123 & -.0074 & $1 / 7312$ & $-1 / 04$ & $2 / 33$ \\
\hline
\end{tabular}

The results of the correlation test between the research variables in Table 3 indicate that the ratio of book value to market has significant and positive correlation with firm size and stock return, beta has significant and positive correlation with stock return, and stock return has significant and positive correlation with the earning per share.

Table 3. correlation test between the research variables

\begin{tabular}{|c|c|c|c|c|c|c|}
\hline Variable & Sign & BM & Beta & Size & RET & $X / P$ \\
\hline $\begin{array}{l}\text { Ratio of book } \\
\text { value to market } \\
\text { value }\end{array}$ & $\mathrm{BM}$ & 1 & & & & \\
\hline Beta & Beta & 0/045 & 1 & & & \\
\hline Firm size & Size & 0/169 & 0/008 & 1 & & \\
\hline Stock return & RET & 0/116 & 0/121 & $-0 / 003$ & 1 & \\
\hline $\begin{array}{l}\text { Earning per } \\
\text { share }\end{array}$ & $\mathrm{X} / \mathrm{P}$ & $\begin{array}{c}\text { 0/072 } \\
*\end{array}$ & 0/033 & 0/011 & $\begin{array}{c}0 / 078 \\
* *\end{array}$ & 1 \\
\hline
\end{tabular}

\section{Regression Results}

\section{The Results of Testing the Hypothesis One}

In order to test the hypothesis, regression 1 model is fit; and the results of the regression model for testing the main hypothesis 2 have been presented in Table 4.

Table 4. The results of testing the hypothesis one

\begin{tabular}{|c|c|c|c|c|c|c|}
\hline Variable name & sign & $\begin{array}{c}\text { (Beta) } \\
\text { coefficient }\end{array}$ & T Statistic & P value & \multicolumn{2}{|c|}{ Linearity study } \\
\hline Fixed amount & $\alpha$ & - & $2 / 866$ & 0/004 & $\begin{array}{l}\text { Special } \\
\text { amounts }\end{array}$ & $\begin{array}{c}\text { Status } \\
\text { indicator }\end{array}$ \\
\hline Earning per share & $(\mathrm{X} / \mathrm{P}) \beta_{1}$ & 0/035 & $0 / 928$ & $0 / 354$ & - & - \\
\hline Changes of the earning per share & $(\Delta X / P) \beta_{2}$ & $\mathbf{0} / \mathbf{0 5 3}$ & $1 / 923$ & $0 / 045$ & $0 / 716$ & 1/397 \\
\hline Indicator of the firm loss & $(\operatorname{LOSS}) \beta_{3}$ & $-0 / 030$ & $-0 / 901$ & $0 / 368$ & $0 / 719$ & 1/391 \\
\hline Modification of share with firm loss & $(X / P \times L O S S)$ & 0/041 & 1/172 & $0 / 242$ & 0/899 & $1 / 112$ \\
\hline Ratio of book value to market value & $(B / M) \beta_{5}$ & 0/053 & $1 / 628$ & 0/104 & $0 / 816$ & $1 / 226$ \\
\hline Firm size & $(\mathrm{SIZE}) \beta_{6}$ & $-0 / 065$ & $-1 / 976$ & $0 / 048$ & $0 / 946$ & 1/057 \\
\hline Systematic risk & (Beta) $\beta_{7}$ & 0/032 & 1/017 & 0/309 & $0 / 931$ & $1 / 075$ \\
\hline \multirow[t]{2}{*}{ Total regression model } & F Statistic & P- value & $\begin{array}{l}\text { Durbin-W } \\
\text { atson } \\
\text { Statistic } \\
\text { (D-W) }\end{array}$ & \multicolumn{3}{|c|}{$\begin{array}{l}\text { Identification coefficient and adjusted } \\
\text { identification coefficient } \\
\text { 0/014 } \mathrm{R}^{2}=\end{array}$} \\
\hline & $2 / 070$ & 0/004 & $1 / 629$ & & $/ 007=\mathrm{Adj}$ & \\
\hline
\end{tabular}


The results of testing the hypothesis one are presented in Table 4. The significance level of $F(0.004)$ is less than acceptable level of error $(5 \%)$ and the total regression model is significant. The results of the test indicate that the changes of the earning per share containing information content have significant and positive effect on future stock return. In addition, the results of the test show that the earning per share containing information content has non-significant and positive effect on future stock return. The results indicate that the size of the firm has significant and negative effect on future stock return. Other variables entering the model do not have a significant effect on future stock return.

\section{Results of Testing the Hypothesis Two}

The hypothesis two states that the ratio of book value to market value of equity in future prediction of stock return is effective considering the mature stage from life cycle stages resulting from the models of firm cash flow.

In order to test this hypothesis, regression model 2 is fit for the stages of the life cycle. In this model if the firm is in the mature stage, code 1 is regarded for it; otherwise code 0 is considered for it.
In mature stage, the sale levels are stabilized and the innovation level decreases. The mature stage is defined as recognition and control stage. Primary investment capacity to meet the high market demand is sufficient in mature stage, and the firm will create more input cash flow. Modification of the mature stage with the lowest ratio of book value to market value can return the firm life cycle to growth stage, due to developing the new product in the future period. However, modifying the highest ratio of book value to market value with the mature stage results in stress reduction toward future stock return due to prediction of firm performance.

Fama et al. [39] found that the ratio of book value to market value of equity has direct and positive correlation with the future stock return and this ratio is the indicator of future potential growth of the firm. The ratio of the book value to market value not only is correlated with future growth and development opportunities of the firm, but also is correlated with other factors such as non-efficiency of capital market or special risk factors of the market. This hypothesis is to measure the highest and lowest ratios of book value to market value in the mature stage and their effect on future stock return.

Table 5. Results of testing the hypothesis two

\begin{tabular}{|c|c|c|c|c|c|c|}
\hline Variable name & sign & $\begin{array}{c}\text { (Beta) } \\
\text { coefficient }\end{array}$ & T Statistic & $P$ value & $\begin{array}{c}\text { Linearity } \\
\text { study }\end{array}$ & $\begin{array}{c}\text { Variable } \\
\text { name }\end{array}$ \\
\hline & & & & & $\begin{array}{l}\text { Special } \\
\text { amounts }\end{array}$ & $\begin{array}{c}\text { Status } \\
\text { indicator }\end{array}$ \\
\hline Fixed amount & $\alpha$ & - & $2 / 822$ & $0 / 005$ & - & - \\
\hline Earning per share & $(\mathrm{X} / \mathrm{P}) \beta_{1}$ & $0 / 043$ & $1 / 135$ & $0 / 257$ & $0 / 710$ & $1 / 409$ \\
\hline Changes of the earning per share & $(\Delta X / P) \beta_{2}$ & $0 / 070$ & $1 / 850$ & $0 / 048$ & $0 / 718$ & $1 / 393$ \\
\hline Indicator of the firm loss & $(\operatorname{LOSS}) \beta_{3}$ & $-0 / 015$ & $-0 / 452$ & $0 / 651$ & $0 / 865$ & $1 / 156$ \\
\hline Modification of share with firm loss & $(X / P \times L O S S) \beta_{4}$ & $0 / 042$ & $1 / 201$ & $0 / 230$ & $0 / 814$ & $1 / 229$ \\
\hline Ratio of book value to market value & $(B / M)^{\beta_{5}}$ & $0 / 063$ & $1 / 846$ & $0 / 048$ & $0 / 856$ & $1 / 168$ \\
\hline Firm size & $(\mathrm{SIZE}) \beta_{6}$ & $-0 / 067$ & $-2 / 051$ & $0 / 041$ & $0 / 920$ & $1 / 087$ \\
\hline Systematic risk & (Beta) $\beta_{7}$ & $0 / 034$ & $1 / 064$ & $0 / 288$ & $0 / 983$ & $1 / 017$ \\
\hline Mature stage & (Mature) $\beta_{8}$ & $0 / 064$ & $1 / 386$ & $0 / 166$ & $0 / 468$ & $2 / 137$ \\
\hline $\begin{array}{l}\text { The lowest amount of book value to } \\
\text { market value in maturity stage }\end{array}$ & $\begin{array}{c}(\text { Mature } \times \text { LowB } / M) \\
\beta_{9}\end{array}$ & $0 / 094$ & $1 / 919$ & $0 / 041$ & $0 / 909$ & $1 / 101$ \\
\hline $\begin{array}{l}\text { The Highest amount of book value to } \\
\text { market value in maturity stage }\end{array}$ & $\begin{array}{c}(\text { Mature } \times \text { HighB } / M) \\
\beta_{10}\end{array}$ & $-0 / 091$ & $-1 / 834$ & $0 / 043$ & $0 / 461$ & $1 / 168$ \\
\hline \multirow[t]{2}{*}{ Total regression model } & Statistic F & $P$ value & $\begin{array}{l}\text { Durbin-Wats } \\
\text { on Statistic } \\
\text { (D-W) }\end{array}$ & \multicolumn{3}{|c|}{$\begin{array}{l}\text { Coefficient of determination and } \\
\text { Modified coefficient of determination } \\
\mathbf{0 / 0 1 4 ~} \mathrm{R}^{2}=\end{array}$} \\
\hline & $2 / 070$ & $0 / 004$ & $1 / 629$ & \multicolumn{3}{|c|}{$\mathbf{0} / \mathbf{0 0 7}=\mathrm{Adj}^{2}$} \\
\hline
\end{tabular}


The results of testing the hypothesis one are presented in Table 5. The significance level of F (0.004) is less than acceptable level of error (5\%) and the total regression model is significant. The results of the test indicate that the changes of the earning per share have significant and positive effect on future stock return. In addition, the results of the test show that the earning per share containing information content has non-significant and positive effect on future stock return. The results indicate that the size of the firm has significant and negative effect on future stock return and the ratio of book value to market value has significant and positive effect on future stock return. The results of the test indicate that the lowest ratio of the book value to market value in mature stage has significant and positive effect on future stock return, and the highest ratio of book value to market value in mature stage has significant and negative effect on future stock return. Other variables entering the model do not have a significant effect on future stock return.

\section{Conclusions}

Considering the result of testing the hypothesis one, changes of the earning per share have significant and positive effect on prediction of future stock return, but the earning per share has non-significant and positive effect on future stock return. The results indicate that the firm size has negative effect on future stock return. As the firm size is larger, its effect is less on stock return, because the firm has more financial power and less risk, so it will naturally have less return.

In the hypothesis two, the results of regression model fit of hypothesis testing indicate that the changes of each share have positive effect on future stock return, but the earning per each share has non-significant and positive effect on future stock return. The test results indicate that the lowest ratio of book value to market value, considering the mature stage has positive effect on stock return, and the its highest amount has negative effect on future stock return considering mature stage. This ratio is the indicator of the difference between book value and market value of the firm. The lowest amount of this ratio indicates the growth opportunities and future potential growth of the firm, and shows that the distance between book value and market value is long. The firms that have growth opportunities are in fact in the mature stage, have information market that exist in share market, but have not been reflected in book value yet, and hence the ratio is low. So, it is expected that the book value (not the market value) of the firms having low book value ratio to market value, grow more rapidly in comparison with the book value of the firms having high book value ratio to market value.

In addition, the results also indicate that control variable of the book value to market value has positive effect and control variable of the firm size has negative effect on future stock return; in fact, the stock return expected by the investors is less from the large firms in comparison with smaller firms. As a result, it is logically expected that there may be a negative relationship between the firm size and the future stock return.

\section{REFERENCES}

[1] Black, E. L. 1998. Life-cycle impacts on the incremental value-relevance of earnings and cash flow measures. Journal of Financial Statement Analysis 4, 40-.56

[2] Anthony, J. and K. Ramesh. 1992. Association between accounting performance measures and stock prices. Journal of Accounting and Economics 15, 203-227.

[3] Aharony, J., H, Falk and N, Yehuda. 2006. Corporate Life Cycle and the Value Relevance of Cash Flow versus Accrual Financial Information, School of Economics and Management Bolzano, Italy, Working Paper No. 34.

[4] Xu, Bixia. 2007. Life Cycle Effect On the Value Relevance of Common Risk Factor. Review of Accounting and Finance Vol. 6 pp.162-175.

[5] Collins, D. Hribar. ,P. and X. Tian. 2012. Cross sectional variation cash flow asymmetric timeliness and its effect on the Earnings-Based measure of conditional conservatism. Working paper. University of Iowa.

[6] Yan, Z. 2010. A new methodology of measuring firm life cycle stages. International journal of economic perspective.

[7] Gardner, J. W. 1965. How to prevent organizational dry rot. Harpers Magazine.

[8] Kallunki, J., Silvola, H. 2008. The effect of organizational life cycle stage on the use of activity-based costing. Management Accounting Research Vol.19, pp.62-79.

[9] Cao, Y. 2012. Mecelcch- Fdp: Financial distress prediction with classifer ensembles based on firm life cycle and choquet integral. Expert systems with applications 39, PP 7041-7049.

[10] Thanatawee, Y. 2011. Life cycle theory and free cash flow hypothesis: Evidence from dividend policyin Thailand. International journal of financial research 2 (2).

[11] DeAngelo, H., DeAngelo, L., and M. S. Rene. 2006. Dividend policy and the earned/contributed capital mix: Atest of the life cycle theory. Journal of financial economics 81, PP 227-254.

[12] Dickinson, V. 2011. Cash Flow Patterns as a Proxy for Firm Life Cycle. The Accounting Review 86, No. 6.

[13] Chen, Y., R. Cheng, A and Y., L, Hung. 2012. Value of cash holding: the impact of cash from operating, Investment and financing activities. National cheng kung university: Working paper NO 48.

[14] Ramalingegowda, S., Wang, C., and Y, Yu. 2013. The role of financial reporting quality in mitigating the constraining effect of dividend policy on investment decisions. The accounting review, 88.

[15] Greiner, L., E. 1998. Evolution and revolution as organizations grow. Harvard business review, pp 3-11. 
[16] Gort, M. and S. Klepper. 1982. Time paths in the diffusion of product innovation. Economic Journal 92, 630-653.

[17] Miller, D., and P. H., Friesen. 1984. A longitudind study of the corporate life cycle. Management science, 30 (10), pp 1161-1183.

[18] Adizes, I. 1989. Corporate Life Cycle: How and Why Corporations Grow and Die and What Do about it. Englewood Cliffs, NJ.

[19] Stepanyan, G. G. 2012. Revigiting firm life cycle theory for new directions in finance. IESEG school of management (LEM-CNRS) socle de la grande arche.

[20] Moors, K, and S. Yuen. 2001. Management accounting systems and organizational configuration; A life cycle perspective accounting organization and society $26 . \mathrm{pp}$ 351-389.

[21] Spence, M. 1979. Investment strategy and growth in a new market. Bell Journal of Economics 10, 1-19.

[22] Jovanovic, B., and G. MacDonald. 1994. The life cycle of a competitive industry. Journal of political economy 102(2): 322-347.

[23] Cox, W. 1967. Product life cycles as marketing models. Journal of business 40(4): 375-384.

[24] Nissim, D. and S. Penman. 2001. Ratio analysis and equity valuation: From research to practice. Review of Accounting Studies 6, 109-154.

[25] Jovanovic, B. 1982. Selection and the evolution of industry. Econometrica 50, 649-70.

[26] Barclay, M., and C. Smith, Jr. 2005. The capital structure puzzle: The evidence revisited. Journal of Applied Corporate finance 17 (1): 8-17.

[27] Livant, J., and P. Zarowin. 1990. The incremental information content of cash flow components. Journal of accounting and economics 13(1): 25-46.

[28] Westerfield, R., Jordan. 2002. Fundamentals of corporate finance; $4^{\text {th }}$ ed., McGraw Hill.

[29] Spence, M. 1977. Entry, capacity, investment, and oligopolistic pricing. Bell Journal of Economics 8, 534-544.

[30] Spence, M. 1981. The learning curve and competition. Bell Journal of Economics 12, 49-70.

[31] Wernerfelt, B. 1985. The dynamics of prices and market shares over the product life cycle. Management Science 31, 928-939.

[32] Hannan, M., and J. Freeman. 1984. Structural inertia and organizational change. American sociological review 49(2): 149-164.

[33] Diamond, D. 1991. Monitoring and reputation: The choice between bank loans and directly placed debt. Journal of Political Economy 99, 689-721.

[34] Myers, S. 1984. The capital structure puzzle. Journal of finance 39(3): 575-592.

[35] Myers, S. 1977. Determinants of corporate borrowing. Journal of financial economics 5 (2): 147-175.

[36] Jensen, M. 1986. The agency costs of free cash flows, corporate finance, and takeovers. American economic review 76 (2): 323-329.

[37] Wang ming- hui, day- yang liu. 2009. Dividend policy and life cycle hypothesis, www.ssrn.com.

[38] Collins, D. and S. P. Kothari. 1989. An analysis of intertemporal and cross-sectional determinants of earnings response coefficients. Journal of Accounting and Economics $11,143-182$.

[39] Fama, E. F. and K. R. French. 1992. The cross-section of expected stock returns. Journal of Finance 47, 427-465.

[40] Hayn, C. 1995. The information content of losses. Journal of accounting and economics 20, 125-153.

[41] Basu, S. 1997. The conservatism principle and the asymmetric timeliness of earnings. Journal of Accounting and Economics 24, 3-37. 